\title{
ESTABLISHMENT OF ANAMMOX PROCESS IN SLUDGE SAMPLES COLLECTED FROM SWINE WASTEWATER TREATMENT SYSTEM
}

\author{
CAROLINE G. CASAGRANDE ${ }^{1}$, AIRTON KUNZ ${ }^{2}$, HUGO M. SOARES ${ }^{3}$, \\ MARINA C. DE PRÁ ${ }^{4}$, GUILHERME F. SCHIERHOLT NETO ${ }^{5}$
}

\begin{abstract}
The high load of nitrogen present in swine wastewater is one of the biggest management challenges of the activity. The Anammox process emerges as a good alternative for biological removal of nitrogen. This study aims to acclimate sludge collected from swine effluent treatment systems to establish the Anammox process. Two sludge samples were collected at Embrapa Swine and Poultry, Concordia - SC, Brazil, one from the bottom of an inactive anaerobic pond (inoculum A) and another from an aeration tank (inoculum B). Both were acclimated until the depletion of $\mathrm{NO}_{3}{ }^{-} \mathrm{N}$, being subsequently inoculated in two reactors (Reactor $\mathrm{A}$ - Inoculum $\mathrm{A}$ and Reactor B - Inoculum B). The Reactor A showed activity after 110 days of operation, while the Reactor B needed 170 days. The difference in the start-up time could be explained by the different environmental conditions to which each sludge was submitted. FISH and PCR analyses confirmed the presence of microorganisms with Anammox activity, demonstrating that the sludge of swine wastewater treatment systems is a good source of inoculum for the development of the Anammox process.
\end{abstract}

KEYWORDS: nitrogen removal, swine wastewater, Anammox process.

\section{ESTABELECIMENTO DO PROCESSO ANAMMOX A PARTIR DE LODO DE SISTEMA DE TRATAMENTO DE EFLUENTE DA SUINOCULTURA}

RESUMO: A elevada carga de nitrogênio presente em efluentes da suinocultura é um dos maiores desafios de manejo da atividade. O processo Anammox surge como boa alternativa para a remoção biológica desse nutriente. Este trabalho teve como objetivo aclimatar diferentes amostras de lodos de sistemas de tratamento de efluentes da suinocultura com vistas ao estabelecimento do processo Anammox. Dois inóculos foram coletados na Embrapa Suínos e Aves, Concórdia - SC, um dos quais no fundo de uma lagoa anaeróbia inativa (Inóculo A) e o outro, em um tanque de aeração (Inóculo B). Ambos foram aclimatados até cessar o consumo de $\mathrm{N}_{-} \mathrm{NO}_{3}{ }^{-}$e, posteriormente, inoculados em dois reatores (Reator A - Inóculo A e Reator B - Inóculo B). O Reator A apresentou atividade, após aproximadamente 110 dias de operação, enquanto o Reator B precisou de aproximadamente 170 dias, diferença de tempo de partida que pode ser explicada pelas diferentes condições ambientais a que cada lodo estava submetido. As análises de FISH e PCR comprovaram a presença de microrganismos com atividade Anammox, mostrando que lodos de sistemas de tratamento de efluentes da suinocultura podem ser boa fonte de inóculo para o desenvolvimento do processo Anammox.

PALAVRAS-CHAVE: remoção de nitrogênio, dejetos de suínos, anammox.

\footnotetext{
${ }^{1}$ Departamento de Engenharia Química, UFSC, Florianópolis - SC, carol_casagrande@ hotmail.com.

${ }^{2}$ Embrapa Suínos e Aves, Concórdia - SC, airton@cnpsa.embrapa.br.

${ }^{3}$ Departamento de Engenharia Química, UFSC, Florianópolis - SC.

${ }^{4}$ Departamento de Engenharia Ambiental, UnC, Concórdia - SC.

${ }^{5}$ Departamento de Engenharia Química, UFSC, Florianópolis - SC.

Recebido pelo Conselho Editorial em: 14-6-2010

Aprovado pelo Conselho Editorial em: 26-11-2010
} 


\section{INTRODUCTION}

The animal production industry has undergone major changes in the last decades, restricting a large number of animals to small areas, called Confined Animal Production Systems (CAPSs) (KUNZ et al., 2009). In the swine industry, the high load of nutrients, particularly nitrogen and phosphorus (DOS SANTOS et al., 2007), coupled with the large volume of waste, are the major challenges to make the activity environmentally viable.

The disposal of wastewaters from pig farming in the soil may provide nutrient overloading, eventually contaminating the surface and groundwater. It is thus necessary to know the loading capacity of each soil-plant system to establish the most appropriate application rate (SAMPAIO et al., 2010). As in most cases, there is no sufficient cropland to technically and economically enable the disposal of effluents, thus being necessary the use of waste treatment strategies.

Among the treatment alternatives for biological removal of nitrogen, there are conventional processes (autotrophic nitrification - heterotrophic denitrification) and advanced techniques, such as the Anammox process (Anaerobic Ammonium Oxidation) preceded by a system of partial nitrification.

The Anammox process was discovered recently and consists of the direct oxidation of ammonium to nitrogen gas using nitrite as electron acceptor (eq.(1)) (STROUS et al., 1998). Part of the $\mathrm{NO}_{2}{ }^{-}$is oxidized to $\mathrm{NO}_{3}{ }^{-}$, generating reducing equivalents for $\mathrm{CO}_{2}$ fixation and subsequent biomass growth.

$$
\mathrm{NH}_{4}^{+}+1,32 \mathrm{NO}_{2}^{-}+0,066 \mathrm{HCO}_{3}^{-}+0,13 \mathrm{H}^{+} \rightarrow 1,02 \mathrm{~N}_{2}+0,26 \mathrm{NO}_{3}^{-}+0,066 \mathrm{CH}_{2} \mathrm{O}_{0,5} \mathrm{~N}_{0,15}+2,03 \mathrm{H}_{2} \mathrm{O}
$$

The process is chemolithoautotrophic, which does not require organic carbon as energy source, occurring in anoxic conditions within temperature ranging between 20 and $43{ }^{\circ} \mathrm{C}$, and undergoing reversible inhibition in the presence of oxygen (STROUS et al., 1999).

The bacteria show an estimated division time of eleven days (JETTEN et al., 2001), indicating a quite limited autotrophic growth. According to the overall stoichiometry of the reaction (eq.(1)), the conversion factor (Y) is $0.066 \mathrm{molCH}_{2} \mathrm{O}_{0,5} \mathrm{~N}_{0,15} / \mathrm{mol} \mathrm{NH}_{4}{ }^{+}$. The low conversion rate of substrate into biomass reduces the costs with treatment and final disposal of the sludge (NI et al., 2010).

The capacity of removing high loads of nitrogen in the order of $17.4 \mathrm{~kg} \mathrm{~m}^{-3} \mathrm{~d}^{-1}$ with a hydraulic retention time of $0.43 \mathrm{~h}$ (CHO et al., 2010) is one of the great advantages of the process, thus allowing the use of small reactors.

Active Anammox microorganisms have been detected from several sources, such as sludge systems from wastewater treatment (DAPENA-MORA et al., 2004), slaughterhouse effluents (REGINATTO et al., 2005), freshwater environments (SCHUBERT et al., 2006), marine sediments (TAL et al., 2005) among others.

Thus, the objective of this study was to acclimatize sludge from two wastewater treatment systems from the swine industry and inoculate two reactors aiming to establish the Anammox process.

\section{MATERIAL AND METHODS}

\section{Sludge sampling}

The sludge samples used for acclimatization were collected at Embrapa Swine and Poultry, Concordia - SC, Brazil $\left(27^{\circ} 18^{\prime} 46^{\prime}\right.$ 'S latitude and $51^{\circ} 59^{\prime} 15^{\prime \prime} \mathrm{W}$ longitude), at two different points: one at the bottom of an inactive anaerobic pond in the demonstration unit, called Inoculum $\mathrm{A}$ (KUNZ et al., 2007) and the other sample from an aeration tank of activated sludge system, located at the Swine Waste Treatment Plant, called Inoculum B (KUNZ et al., 2009). 


\section{Pretreatment}

The sludge samples were previously washed with distilled water and subsequently inoculated in a solution of $\mathrm{NO}_{3}{ }^{-} \mathrm{N}\left(100 \mathrm{mg} \mathrm{L}{ }^{-1}\right)$, under agitation of approximately $100 \mathrm{rpm}$. The decay of nitrate was monitored, and the solution was replaced whenever there was partial consumption. This strategy was used to remove the biodegradable carbon in the sludge (KUNZ et al., 2007).

\section{Settings and inoculation of the reactors}

Two piston-flow tubular reactors filled up with half polymer support shaped as a net, Biofix, with a 2-L volume (Figure 1) were inoculated with sludge collected as described above at $4 \mathrm{~g} \mathrm{~L}^{-1}$ TSS. The feeding was performed with synthetic medium (SCHIERHOLT NETO, 2007), with initial concentration of $\mathrm{N}-\mathrm{NH}_{3}$ and $\mathrm{NO}_{2}^{-}-\mathrm{N} \mathrm{mg} \mathrm{L}^{-1}$. $\mathrm{N}_{2}$ was injected until the dissolved oxygen concentration reached $0.5 \mathrm{mg} \mathrm{L}^{-1}$, to avoid contamination by oxygen. The HRT (hydraulic retention time) was fixed at $24 \mathrm{~h}$ and the temperature maintained at $35^{\circ} \mathrm{C}$. Due to the low division time of the bacteria, it was decided to work with biofilm reactors, due to their greater retention of solids in relation to reactors with suspended biomass.
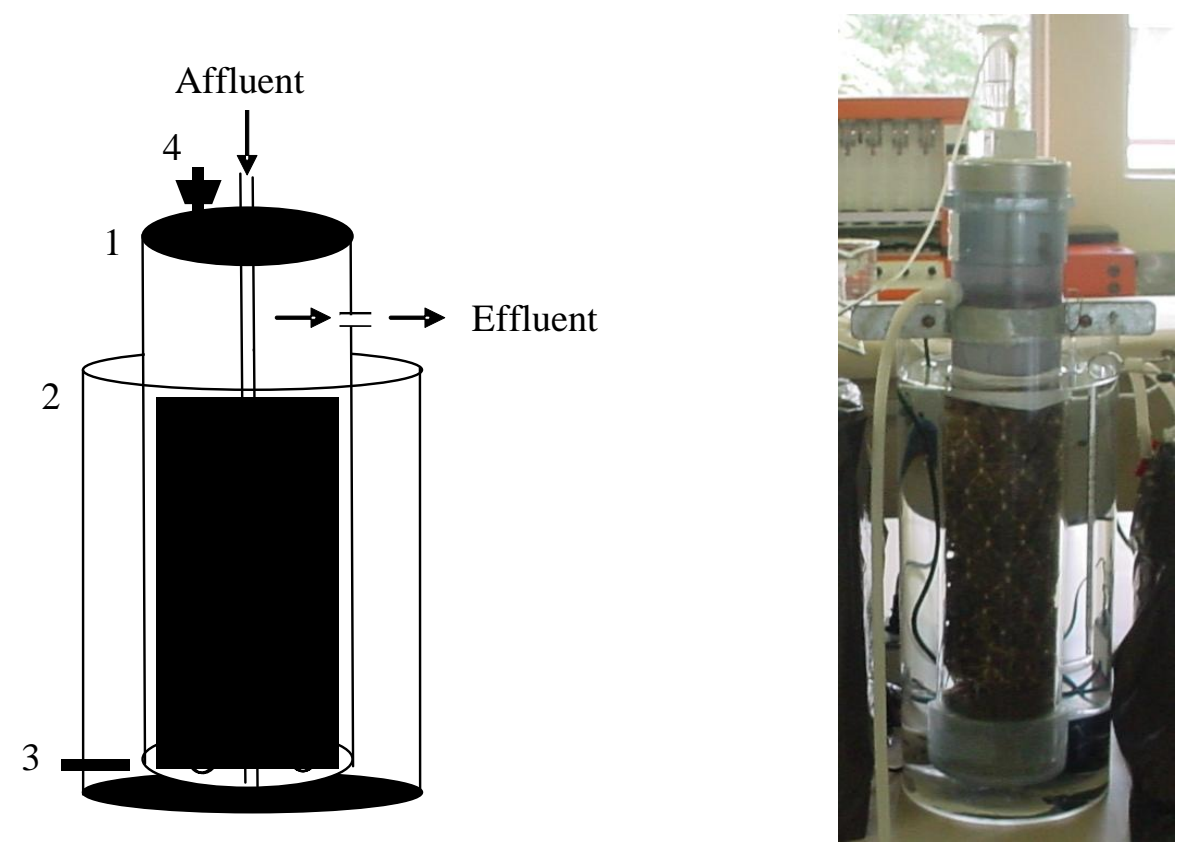

FIGURE 1. Configuration of the reactors used to the sludge samples inoculation. (1) reactor, (2) heated bath, (3) electric heater, (4) gases output, support medium.

\section{Monitoring the Anammox activity}

Consumption of ammonia, nitrite, alkalinity, and production of nitrate was monitored in the affluent and effluent samples. $\mathrm{NH}_{3}-\mathrm{N}$ analyses were carried out by potentiometry, $\mathrm{NO}_{2}{ }^{-}-\mathrm{N}$ and $\mathrm{NO}_{3}-\mathrm{N}$ were monitored by colorimetry and the alkalinity by titration. All analyses were performed according to APHA (1995). To display the trend of Anammox activity, the analyses were performed weekly initially, being later performed twice a week.

The establishment of the Anammox activity was followed by the stoichiometric coefficients of the global reaction. As in eq.(1), we considered the fact that in the literature (STROUS et al., 1998), the ammonium ion component has coefficient 1.0, in order to calculate the coefficients of the nitrite and nitrate ions, according to eqs.(2) and (3), respectively.

$$
\text { Coeficiente } \mathrm{NO}_{2}^{-}=\frac{\text { Carga de } \mathrm{NO}_{2}^{-} \text {convertida no dia } \mathrm{z}}{\text { Carga de } \mathrm{NH}_{4}^{+} \text {convertida no dia } \mathrm{z}}
$$




$$
\mathrm{NO}_{3}^{-} \text {Coeficient }=\frac{\mathrm{NO}_{\mathrm{g}}^{-} \text {loadproduce in the } \mathrm{zday}}{\mathrm{NH}_{4}^{+} \text {load converted in the } \mathrm{z} \text { day }}
$$

where,

$\mathrm{z}$ - a day of any observation.

\section{Microbiological characterization}

To characterize the microorganisms present in the reactor, FISH (Fluorescence In Situ Hybridization) and PCR (Polymerase Chain Reaction) analyses were carried out.

In the FISH analysis, it was used the probes Amx 380, aiming to detect bacteria with Anammox activity (Candidatus Brocadia anammoxidans and Candidatus Kuenenia stuttgartiensis) and Nso 190 (which detects all Ammonia-oxidizing bacteria - AOBs-of the Proteobacteria of the beta group, genera Nitrosomonas, Nitrosospira, Nitrosococcus, Nitrosovibrio, Nitrosolobus), following methodology described by SCHIERHOLT NETO (2007). Bacteria quantification was performed by visual estimation and comparison, within the same optical field, the cells were stained with DAPI (4',6-diamidino-2-phenylindole, which dyes all bacterial cells) against the cells stained with the probe (SCHIERHOLT NETO, 2007).

For PCR, specific primers were used for bacteria with Anammox activity (Pla 46F and Amx $820 \mathrm{R}$ ), aimed at amplifying a fragment of about 850 base pairs (bp). The primers and amplification conditions were performed as described by VIANCELLI et al. (2009).

Two collections were performed for FISH analysis, one of the sludge after acclimation at 63 days of operation, and a composite sample of the support medium in the Reactor A, at 150 days of operation. For PCR analysis, four samples were collected at different points in the reactor (at the top, middle, bottom and side) at 150 days of operation.

\section{RESULTS AND DISCUSSION}

\section{Start up phase of the reactor}

The acclimation phase lasted 30 days. In Figure 2, it can be seen that there was more nitrate consumption from day 8 for Inoculum A and from day 28 for the Inoculum B, indicating the end of the activity of heterotrophic microorganisms (i.e., end of the denitrification process) and consumption of organic matter.

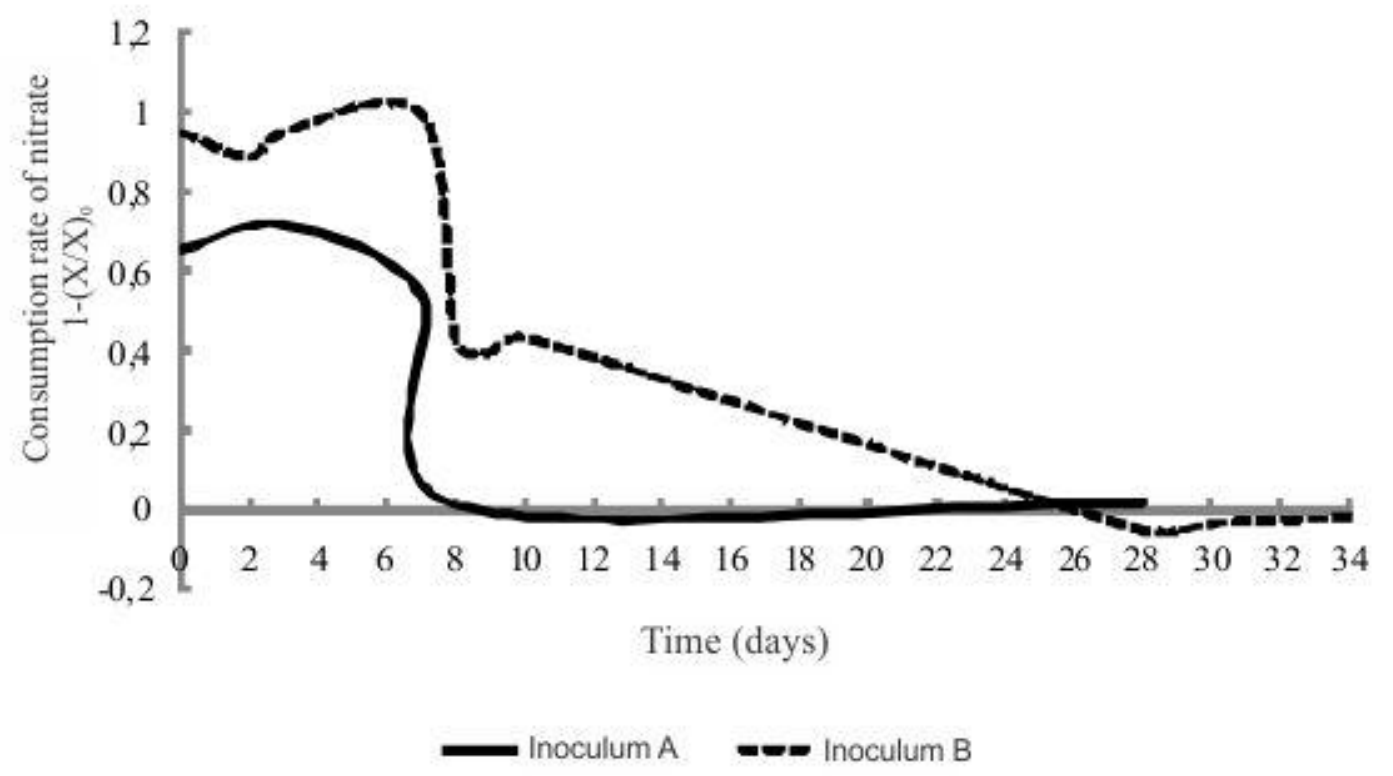

FIGURE 2. Consumption of $\mathrm{NO}_{3}{ }^{-}-\mathrm{N}$ for sludge $\mathrm{A}$ and $\mathrm{B}\left(\mathrm{Xo}=\right.$ initial concentration of $\mathrm{NO}_{3}{ }^{-} \mathrm{N}$ and $\mathrm{X}=$ final concentration of $\mathrm{NO}_{3}^{-}-\mathrm{N}$, both in $\mathrm{mg} \mathrm{L}^{-1}$. 
The difference in degradation time of the organic matter between the two inoculants is due to the type of biomass and the environmental conditions to which the organic matter was submitted. The inoculum A had a low concentration of organic matter, since it was collected in an anaerobic pond that was no longer being fed and was exposed to the denitrification process, while the inoculum B was collected in an active reactor that was regularly receiving high loads of organic matter.

After acclimation, the reactors were inoculated and named Reactor A (inoculated with inoculum A) and Reactor B (inoculum B). As for the acclimation phase, the reactors showed different responses regarding start up time.

In the first 90 days after inoculation, due to the low rate of bacteria replication, $\mathrm{NH}_{3}{ }^{-} \mathrm{N}^{-} \mathrm{NO}_{2}{ }^{-}$ $\mathrm{N}$ and $\mathrm{NO}_{3} \mathrm{~N}$ were monitored weekly, with no Anammox activity (data not shown).

At approximately 110 days, the Reactor A demonstrated Anammox activity, with outputs of $\mathrm{NH}_{3}{ }^{-} \mathrm{N}$ and $\mathrm{NO}_{2}{ }^{-} \mathrm{N}$ very close to zero, and production of $\mathrm{NO}_{3}{ }^{-} \mathrm{N}$ (Figure 3a), as well as the stoichiometric coefficients close to those found by STROUS et al. (1998) (Figure 3b). The start of activity led to an increase of effluent concentration up to $120 \mathrm{mg} \mathrm{L}^{-1}$, with continued activity represented by the stoichiometric coefficients of the global reaction.
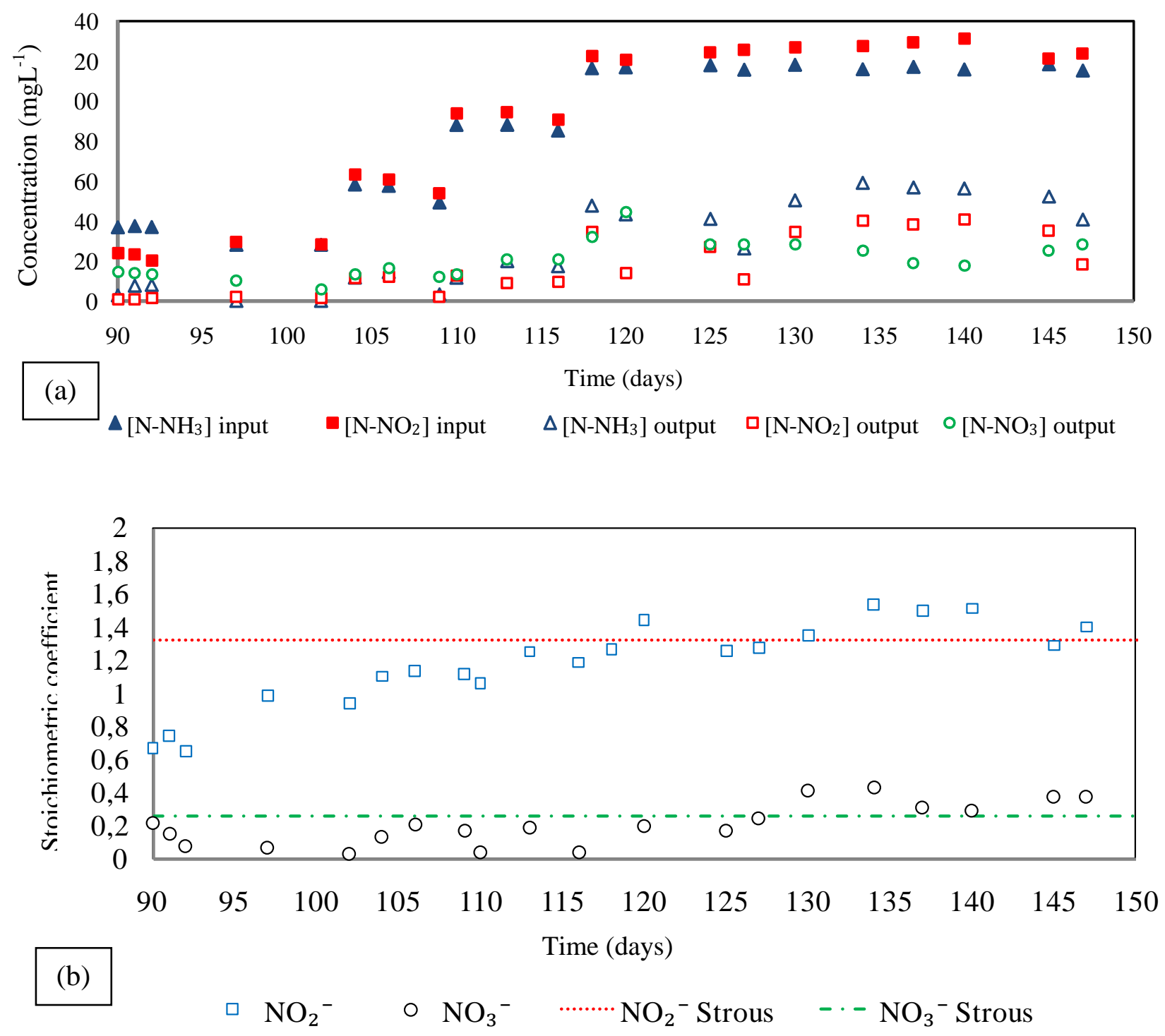

FIGURE 3. a) Changes in concentration of nitrogen species in Reactor A. b) Monitoring of the stoichiometric coefficients in Reactor A. 
For operational reasons, even with no activity, the Reactor B presented the same load progression as the reactor $\mathrm{A}$, which extended its start up time. Soon, the feeding concentration returned to the initial $30 \mathrm{mg} \mathrm{L}^{-1}$. At 170 days of operation, the stoichiometric coefficients were close to those values reported by STROUS et al. (1998), and at approximately 210 days, the Anammox process was finally established (Figure 4).

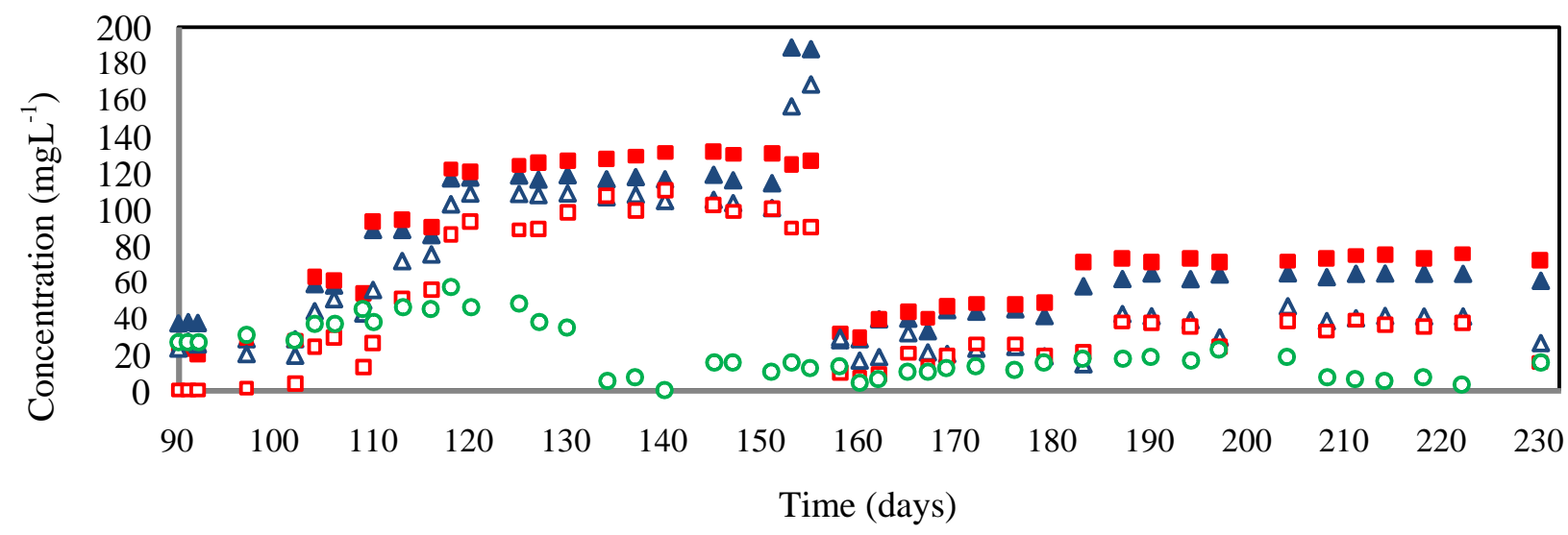

(a) $\Delta\left[\mathrm{N}-\mathrm{NH}_{3}\right]$ input $\quad \Delta\left[\mathrm{N}-\mathrm{NO}_{2}\right]$ input $\Delta\left[\mathrm{N}-\mathrm{NH}_{3}\right]$ output $\square\left[\mathrm{N}-\mathrm{NO}_{2}\right]$ output $\circ\left[\mathrm{N}-\mathrm{NO}_{3}\right]$ output

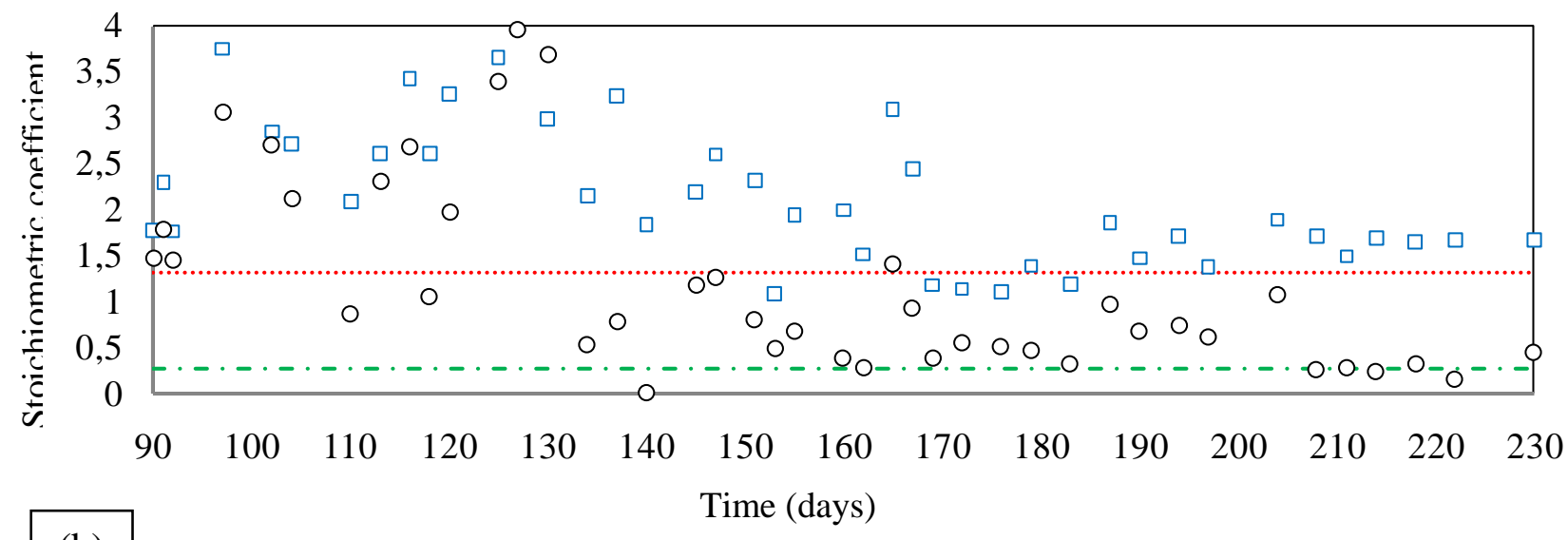

(b)

$$
\square \mathrm{NO}_{2}^{-} \quad \mathrm{O} \mathrm{NO}_{3}^{-} \quad \cdots \cdots . . . \mathrm{NO}_{2}^{-} \text {Strous } \quad-\cdot-\mathrm{NO}_{3}{ }^{-} \text {Strous }
$$

FIGURE 4. a) Changes in concentration of nitrogen species in Reactor B. b) Monitoring of the stoichiometric coefficients in Reactor B.

\section{Microbiological characterization}

FISH analysis showed positive results for both samples (sludge after acclimatization and the composed sample in Reactor A) for the probes Amx 380 and Nso 190, confirming the presence of microorganisms with Anammox activity and ammonia-oxidizing bacteria.

The acclimated sludge sample showed 20\% AOBs and 2\% bacteria with Anammox activity whereas the acclimated sludge sample B showed $60 \%$ AOBs and $1 \%$ of bacteria with Anammox activity. The highest amount of AOBs observed in the Inoculum B relative to Inoculum A is explained by the different environmental conditions to which the sludge samples had been subjected.

The compound sample in the Reactor A consists, collected at 150 days of operation showed a higher amount of bacteria with Anammox activity in relation to AOBs. Figure 5a shows the 
presence of bacteria with Anammox activity in relation to DAPI, where almost all the bacterial cells (stained with DAPI) visualized were also stained with the Amx 380probe, indicating a very enriched culture.

PCR analysis using primers specific for bacteria with Anammox activity (Pla 46F and AMX $820 \mathrm{R}$ ) showed positive results for all four samples collected in the reactor, at 150 days of operation (Figure 5. B). The detection of a 850-bp fragment as shown in Figure $5 \mathrm{~b}$ is indicative of the presence of the target region for which the amplification reaction (PCR) was developed, i.e., by the PCR mentioned above, thus enabling to detect the presence of the bacterial genome in different samples tested.
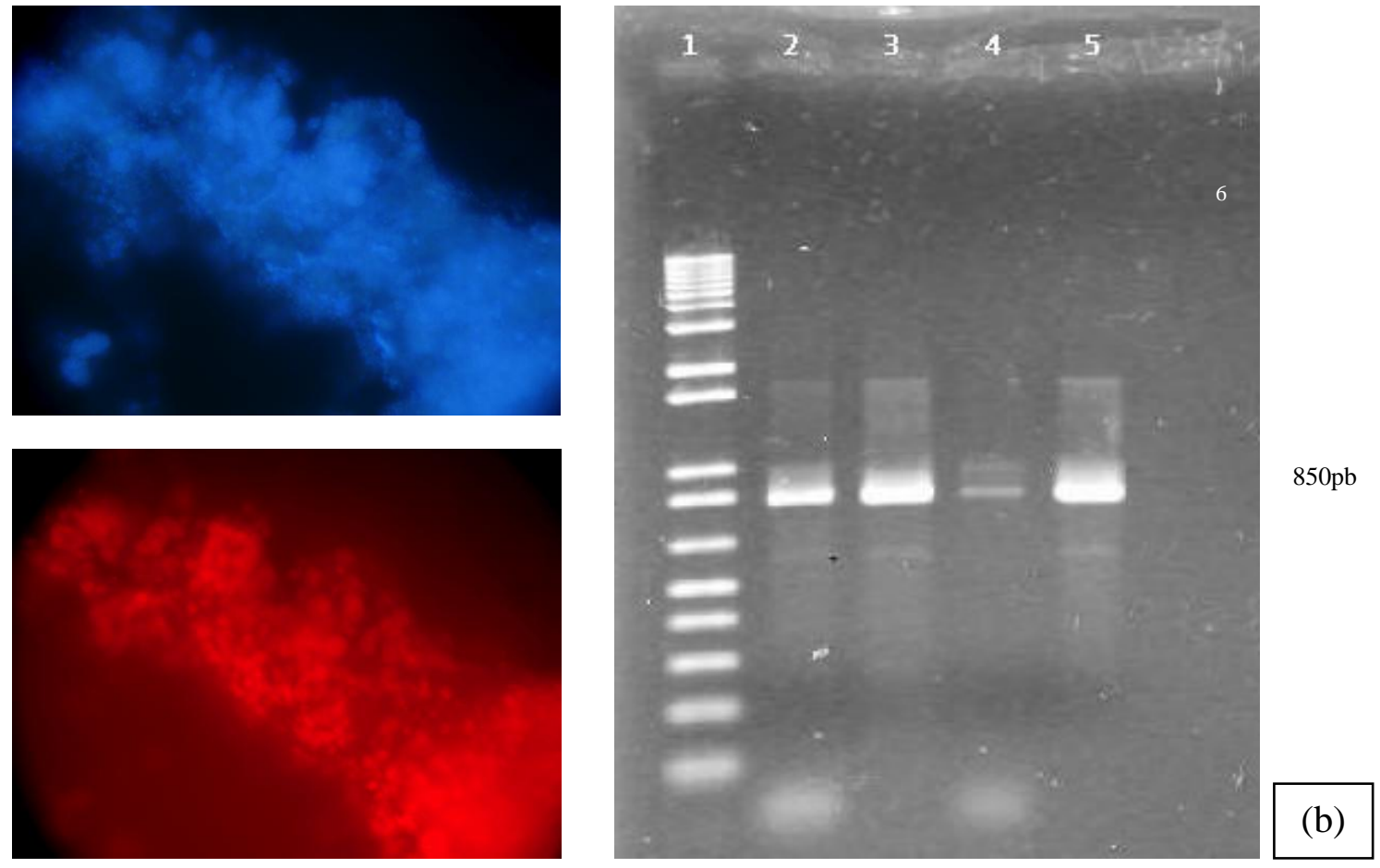

FIGURE 5. a) FISH: compound sample of Reactor A, stained with DAPI in blue, and in red stained with Amx 380. b) PCR: qualitative results confirm the presence of activity Anammox bacteria, where the first column represents the pattern (Ladder - brand Promega), the columns 2;3; 4 and 5 represent samples collected at different points of the reactor during operation time, and column 6 represents the negative control.

\section{CONCLUSIONS}

The treatment process of sludge samples from swine farming effluent proved to be a good source of inoculum for the development of the Anammox process, provided that the samples are given favorable operating conditions to allow for the selection of these microorganisms.

The stoichiometric coefficients of the global reaction, along with FISH and PCR analyses, confirmed the presence of bacteria with Anammox activity and its process development.

\section{ACKNOWLEDGMENT}

To CNPq and PIBIC for the undergraduate research scholarships. 


\section{REFERENCES}

APHA/AWWA/WEF. Standard methods for the examination of water and wastewater. $19^{\text {th }}$ ed. American Public Health Association, 1995.

CHO, S.; TAKAHASHI, Y.; FUJII, N.; YAMADA, Y.; SATOH, H.; OKABE, S. Nitrogen removal performance and microbial community analysis of an anaerobic up-flow granular bed anammox reactor. Chemosphere, Oxford, v.78, p.1129-1135, 2010.

DAPENA-MORA, A.; VAN HULLE, S.W.H.; CAMPOS, L.J.; MÉNDES, R.;

VANROLLEGHEM, P.A.; JETTEN, M. Enrichment of Anammox biomass from municipal activated sludge: experimental and modelling results. Journal of Chemical Technology and Biotechnology, London, v.79, p.1421-1428, 2004.

JETTEN, M.S.M.; WAGNER, M.; FUERST, J.; VAN LOOSDRECHT, M.; KUENEN, G.; STROUS, M. Microbiology and application of the anaerobic ammonium oxidation ("anammox") process. Current Opinion in Biotechnology, London, v.12, p.283-288, 2001.

KUNZ, A.; MIELE, M.; STEINMETZ, R.L.R. Advanced swine manure treatment and utilization in Brazil. Bioresource Technology, Essex, v.100, p.5485-5489, 2009.

KUNZ, A.; VANOTTI, M.; SZOGI, A.; GONZALEZ, M.C.G.; SCHIERHOLT NETO, G.F.; SOARES, H.M. Development of anammox process for animal treatment: experiences in Brazil. In: INTERNATIONAL SYMPOSIUM ON AIR QUALITY AND WASTE MANAGEMENT, 2007, Bromsfield. Proceedings... St. Joseph : ASABE, 2007. p.1-4.

NI, S.; LEE, P.; FESSEHAIE, A.; GAO, B.; SUNG, S..Enrichment and biofilm formation of Anammox bacteria in a non-woven membrane reactor. Bioresource Technology, Essex, v.101, p.1792-1799, 2010.

REGINATTO, V.; TEIXEIRA, R.M.; PEREIRA, F.; SCHMIDELL, W.; FURIGO, A.J.; MENES, R.; ETCHEBEHERE, C.; SOARES, H.M. Anaerobic ammonium oxidation in a bioreactor treating slaughterhouse wastewater. Brazilian Journal of Chemical Engineering, São Paulo, v.22, p.593600, 2005.

SAMPAIO, S.C.; FIORI, M.G.S.; OPAZO, M.A.U.; NÓBREGA, L.H.P. Comportamento das formas de nitrogênio em solo cultivado com milho irrigado com água residuária da suinocultura. Engenharia Agrícola, Jaboticabal, v.30, n.1, p.138-149, jan./fev. 2010

DOS SANTOS, M.A.A.; SCHMIDT, V.; BITENCOURT, V.C.; MAROSO, M.T.D. Esterqueiras: avaliação físico-química e microbiológica do dejeto suíno armazenado. Engenharia Agrícola, Jaboticabal, v.27, n.2, p.537-543, maio/ago. 2007.

SCHIERHOLT NETO, G.F. Desenvolvimento de uma flora de microrganismos oxidadores anaeróbios de amônia utilizando inóculos provenientes de dejeto de suíno. 2007. $115 \mathrm{f}$.

Dissertação (Mestrado em Engenharia Química) - Universidade Federal de Santa Catarina, Florianópolis, 2007.

SCHUBERT, C.J.; DURISCH-KAISER, E.; WEHRLI, B.; THAMDRUP, B.; LAM, P.; KUYPERS, M.M.M. Anaerobic ammonium oxidation in a tropical freshwater system (Lake Tanganyika). Environmental Microbiology, Oxford, p.1462-2920. 2006

STROUS, M.; HEIJNEN, J.J.; KUENEN, J.G.; JETTEN, M.S.M. The sequencing batch reactor as a powerful tool for the study of slowly growing anaerobic ammonium - oxidizing microorganisms. Applied and Microbiology and Biotechnology, Berlin, v.50, p.589-596, 1998.

STROUS, M.; KUENEN, J.G.; JETTEN, M.S.M. Key physiology of anaerobic ammonium oxidation. Applied and Environmental Microbiology, Washington, v.49, p.236-244, 1999. 
TAL, Y.; WATTS, J.E.M.; SCHREIER, H.J. Anaerobic ammonia-oxidizing bacteria and related activity in baltimore inner harbor sediment. Applied and Environmental Microbiology, Washington, v.71, p.1816-1821, 2005.

VIANCELLI, A.; KUNZ, A.; ESTEVES, P.A.; NISHIYAMA, T.; FUJII, T.; VANOTTI, M.;

ANTONIO, R.V. Analysis of bacterial community from a sludge reactor with anammox activity. In: SIMPÓSIO INTERNACIONAL SOBRE GERENCIAMENTO DE RESÍDUOS DE ANIMAIS, 1., 2009, Florianópolis. Anais... p.502-506, 2009. 